\title{
Optimum Oil Palm Shell Content as Coarse Aggregate in Concrete Based on Mechanical and Durability Properties
}

\author{
Mehdi Maghfouri (D), 1 Payam Shafigh $\left(\mathbb{D},{ }^{2,3}\right.$ and Muhammad Aslam ${ }^{4}$ \\ ${ }^{1}$ Department of Civil Engineering, Faculty of Engineering, University of Malaya, 50603 Kuala Lumpur, Malaysia \\ ${ }^{2}$ Department of Building Surveying, Faculty of Built Environment, University of Malaya, 50603 Kuala Lumpur, Malaysia \\ ${ }^{3}$ Center for Building, Construction \& Tropical Architecture (BuCTA), Faculty of Built Environment, University of Malaya, \\ 50603 Kuala Lumpur, Malaysia \\ ${ }^{4}$ Department of Civil Engineering, School of Engineering \& Technology, Institute of Southern Punjab, 60000 Multan, Pakistan
}

Correspondence should be addressed to Mehdi Maghfouri; m.maghfouri@gmail.com and Payam Shafigh; pshafigh@gmail.com

Received 4 August 2018; Accepted 4 November 2018; Published 16 December 2018

Academic Editor: Michelina Catauro

Copyright ( $) 2018$ Mehdi Maghfouri et al. This is an open access article distributed under the Creative Commons Attribution License, which permits unrestricted use, distribution, and reproduction in any medium, provided the original work is properly cited.

Oil palm shell (OPS) is a biosolid waste in palm oil industry in the tropical countries which could be used as aggregate in concrete mixture. Since 1984, OPS has been experimented as natural lightweight aggregate in research studies to produce lightweight concrete (LWC). Medium and high-strength LWCs using OPS as coarse aggregate were successfully produced. However, higher drying shrinkage and lower mechanical properties for concretes containing higher volume of OPS are reported in previous studies. Therefore, OPS is not fit to be used as full coarse aggregate in concrete mixture and therefore, there should be an optimum OPS content in concrete. In this study, in a normal-weight concrete, normal coarse aggregate was replaced with OPS from zero to $100 \%$ with an interval of $20 \%$. Tests such as slump, density, compressive strength in different curing conditions, splitting tensile strength, initial and final water absorptions, and drying shrinkage of cured and uncured specimens were conducted to find out optimum OPS content in concrete. From the test results, it could be summarized that OPS content should not exceed $60 \%$ of total volume of coarse aggregate.

\section{Introduction}

Growing of the human population and consumption of the natural resources lead to production of large quantities of the waste which causes environmental issues. Many of nondecomposed waste materials will remain in the environment for millennium. Therefore, waste management is a way to reduce negative environmental effect and make the waste materials more sustainable $[1,2]$. Concrete simplicity lies in the fact that its constituents are ubiquitous almost anywhere. Nowadays, average 12 billion tones rock and sand are consumed as aggregate in concrete industry annually. This fact shows that enormous volume of raw material has been used to produce concrete in the world [3]. In regard to the huge daily production of concrete, even a small reduction in using the natural raw material leads to remarkable benefit to the environment and avoidance of ecological imbalance [4]. Therefore, the emphasis on sustainable material in order to substitute the natural material has been increased [5]. In the long run, to develop sustainably, the only solution is to have a dramatic improvement to resource efficiency, thereby many researchers have been motivated to investigate utilization of wastes and by-product materials [6].

Any structure is designed intelligently to be as light as possible. In concrete structures, the use of low-density concrete is an effective way to minimize overall dead load and as a result obtain optimum cross-sectional dimensions of reinforced concrete elements [7]. In construction industry, structural low-density concrete is applied with many advantages such as optimization of the structural design by saving in dead weight, reduction of the lateral forces related to the seismic condition, high strength to weight ratio, 
superior sound and heat insulation characteristics, frost and fire resistance, and low coefficient of thermal expansion [8]. However, there are some disadvantages such as limited mechanical properties, requiring more cement content to achieve same strength as normal-weight concrete, greater shrinkage, creep, and prestressing loss in pre-tension structures [9].

Basically, compared to the normal-weight concrete (NWC), lightweight concrete (LWC) has lower mechanical properties. However, the production of high-strength lowdensity concrete with grade up to $100 \mathrm{MPa}$ has been investigated successfully [10]. Using the lightweight aggregate (LWA) together with normal-weight fine aggregate in concrete mixtures is an effective method to produce lightweight aggregate concrete (LWAC). During World War II, lightweight aggregate concrete was utilized for shipbuilding program in north of America when shortages of steel and timber threatened the supply of ships [11].

Generally, the LWAs can be broadly categorized into natural or artificial groups. Diatomite, basaltic pumice, scoria, and tuff are the mostly used LWAs [12]. There are further two different categories under artificial aggregates. The first category is modified naturally arising materials which are obtained through the heat treatment such as shale, expanded clay, slate, and perlite. The second is the industrial by-product materials that also are used as LWAs in construction industry such as sintered slate, sintered pulverized fuel ash, colliery waste, and foamed or expanded blast furnace [8].

In palm oil industry, specially, in tropical countries, the most common agricultural waste is oil palm shell (OPS) $[13,14]$. Abdus Salam et al. [15] for the first time in Malaysia introduced the method of using OPS as a LWA for the manufacture of LWAC. Several researchers have pointed out that conventional coarse aggregate can be replaced with OPS to produce structural grade of LWC. Mannan and Ganapathy [16] studied the failure pattern of oil palm shell concrete (OPSC) under 7 and 90-day water curing condition. They observed that failure patterns in early ages are depending on strength of the OPS aggregate while in the later age, at 90 days, the strong bonding of OPS and paste is governed. Researchers over last twenty years have proven that LWC containing OPS has satisfactory mechanical properties and durability [17]. For OPSC, the compressive strength in the range of 13-22 $\mathrm{MPa}$ was observed by many researchers. Also with the inclusion of fly ash, silica fume, and admixtures, compressive strength of $37 \mathrm{MPa}$ has been obtained. Furthermore, high-strength lightweight concrete with 28-day compressive strength up to $48 \mathrm{MPa}$ with dry density of about 1870 and $1990 \mathrm{~kg} / \mathrm{m}^{3}$ using the crushed OPS and limestone powder has been reported [5, 18].

OPS lightweight concrete grades 30 and $35 \mathrm{MPa}$ were successfully produced by using fly ash at 50\% and $30 \%$ replacement levels of the cement content. However, it has a lower compressive strength than the reference ordinary concrete [18]. Shafigh et al. [18] did a study to compare expanded clay and the OPS lightweight aggregate concretes in terms of drying shrinkage and mechanical properties. Results show that the OPSC has $44 \%$ higher compressive strength and $30 \%$ greater flexural strength. However, the dry density of the expanded clay LWC is $5 \%$ lower than the
OPSC. It was demonstrated that there is a linear relationship between early age and 28-day compressive strength of OPSC made with crushed OPS aggregate [19]. In another experimental study, OPS lightweight concrete was utilized to cast reinforced concrete beams. The result shows satisfactory shear and flexural performances [20, 21]. This type of concrete also has been used to supply industrialised building system (IBS) components such as precast lightweight wall panel for affordable housing in Malaysia.

Previous studies revealed that LWC, by using the OPS, has good mechanical properties and durability performance. However, a good mechanical property is not the only indicator to evaluate the quality of OPS lightweight concrete [22]. This concrete has some drawbacks which need to be considered and rectified before it is applied. High drying shrinkage is one of the main drawbacks compared to the NWC. The drying shrinkage of OPSC was first investigated by Abdullah [23], who reported that drying shrinkage of this type of concrete is about 5 times higher than the NWC. Mannan and Ganapathy [24] also investigated the drying shrinkage of OPSC and NWC up to the age of 90 days. They reported that the drying shrinkage of both types of concretes was increased with age but higher increment was about $14 \%$ higher compared to NWC for OPSC. Drying shrinkage for several types of low-density concrete using OPS with 28-day compressive strength in the range of $22-38 \mathrm{MPa}$ was measured by Alengaram and Awam [25]. They reported that drying shrinkage of OPS at the age of 90 days is in the range of 540-1300 microstrain. Shafigh et al. [18] pointed out that drying shrinkage of OPSC is greater than expanded clay lowdensity concrete of about $100 \%$ at the early ages and about $35 \%$ at the age of 90 days and beyond.

Generally, high cement content and OPS percentage in OPSC are key reasons for its high value of drying shrinkage. Therefore, one of the effective methods to control the drying shrinkage of OPSC is reduction of the volume of OPS aggregate in the concrete mixture [26]. From the previous studies, it was found that there is not any information concerning the optimum OPS content in concrete with acceptable drying shrinkage. Because of the importance of OPS content in concrete, in order to achieve satisfactory mechanical properties and less drying shrinkage, this investigation was carried out to find out the optimum substitution of oil palm shell in conventional concrete to produce durable structural lightweight aggregate concrete. The results of the present study can be effectively used as a reference for production of structural OPS lightweight concrete in precast and construction industry since there is an optimum level of OPS to meet requirements of both mechanical properties and drying shrinkage.

\section{Experimental Programme}

\subsection{Materials}

2.1.1. Cement. Ordinary Portland cement (OPC) which complies to the requirements of MS EN 197-1:2014 CEM 1 $52.5 \mathrm{~N}$ standards with a 2-, 7- and 28-day compressive strength of 25,41 , and $55 \mathrm{MPa}$, respectively, was used as 
binder in this investigation. The specific gravity and Blaine specific surface area of the cement were 3.15 and $3710 \mathrm{~cm}^{2} / \mathrm{g}$, respectively.

2.1.2. Aggregate. The OPS and crushed granite were utilized as coarse aggregates in this study. In order to remove the fibers from the OPS surface, it was stored in an open area for approximately 7 months [19]. OPS aggregates were washed in the concrete mixer using a detergent powder to remove the oil and other impurities from the surface. Then, for having same grading, both granite and OPS were sieved. For the fine aggregate, mining sand with fineness modulus of 2.89 and maximum grain size of $5.0 \mathrm{~mm}$ was used. The mechanical and physical features of the aggregates are represented in Table 1.

2.1.3. Superplasticizer. The chloride-free admixture Sika ViscoCrete was used as superplasticizer in the present research. According to BS 5075, the admixture's dosage should be within the range of $500-2000 \mathrm{ml}$ per $100 \mathrm{~kg}$ of cement, based on strength and workability requirements.

2.1.4. Water. Portable water was utilized for the concrete mixtures and the curing of concrete specimens.

2.2. Mix Proportions and Testing Methods. OPS and crushed granite as coarse aggregate were used for six different concrete mixes. The OPS aggregates were presoaked in water for $24 \mathrm{~h}$ and used in SSD condition. The normal-weight concrete (CM) was considered as control mix, and for other mixes, crushed granite was partially replaced with OPS at 20, $40,60,80$, and $100 \%$ by volume. The volume of aggregates, cement, and SP contents was placed constantly for all the mixes. Mix proportions of all mixes are given in Table 2 .

To produce each concrete mixture, raw materials were combined in a rotating drum mixer, and mixing was continued for two minutes. Then a mixture of $70 \%$ mixing water with SP was added, and mixing continued for another three minutes. Another 5 minutes were applied for mixing of remaining water. After mixing process, the slump test was carried out and followed by taking $100 \mathrm{~mm}$ cubes for compression test, cylinders of $100 \mathrm{~mm}$ diameter and $200 \mathrm{~mm}$ height for splitting tensile test, and prisms of $100 \times 100 \times$ $300 \mathrm{~mm}$ for drying shrinkage strain. A vibrating table was used for proper compaction of the specimens. After sampling, covered specimens were kept in the laboratory condition and demoulded after $24 \mathrm{~h}$. The demoulded density of all the mixes was measured right after demoulding. Whereas the oven-dry density was measured at the age of 28 days. To evaluate precise value of the mechanical properties at all ages, three test specimens for each mix were prepared, and the average of the results was applied for analysis. Drying process of the specimens was carried out in the oven at $105 \pm$ $5^{\circ} \mathrm{C}$ for the water absorption test. The dried specimens, then, were immersed in water at $23 \pm 3^{\circ} \mathrm{C}$ for the initial $(30$ minutes) and final $(72 \mathrm{~h})$ water absorption tests.
TABle 1: Physical and mechanical properties of fine and coarse aggregates.

\begin{tabular}{lccc}
\hline $\begin{array}{l}\text { Physical and mechanical } \\
\text { properties }\end{array}$ & \multicolumn{2}{c}{$\begin{array}{c}\text { Coarse } \\
\text { aggregate } \\
\text { OPS }\end{array}$} & $\begin{array}{c}\text { Franite } \\
\text { aggregate } \\
\text { Mining sand }\end{array}$ \\
\hline Specific gravity & 1.20 & 2.65 & 2.68 \\
Compacted bulk density $\left(\mathrm{kg} / \mathrm{m}^{3}\right)$ & 610 & 1490 & 1657 \\
24-hour water absorption $(\%)$ & 20.5 & $<1$ & 1.2 \\
Crushing value (\%) & 0.2 & 18.0 & - \\
Impact value (\%) & 5.5 & 15.5 & - \\
Abrasion value (\%) & 5.7 & 22.4 & - \\
\hline
\end{tabular}

TABLE 2: Mix proportions of concrete mixes $\left(\mathrm{kg} / \mathrm{m}^{3}\right)$.

\begin{tabular}{lccccccc}
\hline \multirow{2}{*}{$\begin{array}{l}\text { Mix } \\
\text { code }\end{array}$} & Cement & Water & \multicolumn{2}{c}{ Sand (kg) } & \multicolumn{4}{c}{ Coarse } \\
& & & $0-2 \mathrm{~mm}$ & $0-5 \mathrm{~mm}$ & Granite & OPS & \\
\hline $\mathrm{CM}$ & 55 & 18.7 & 47 & 47 & 103 & - & 0.55 \\
$\mathrm{C} 20$ & 55 & 18.2 & 47 & 47 & 82 & 9.2 & 0.55 \\
C40 & 55 & 18.2 & 47 & 47 & 62 & 18.7 & 0.55 \\
C60 & 55 & 18.2 & 47 & 47 & 41.2 & 28 & 0.55 \\
C80 & 55 & 18.2 & 47 & 47 & 20.6 & 37.3 & 0.55 \\
C100 & 55 & 18.2 & 47 & 47 & - & 46.6 & 0.55 \\
\hline
\end{tabular}

2.3. Curing Conditions. The 28-day compressive strength of the prepared specimens was also examined under different curing conditions. For that purpose, three different curing conditions were applied as follows:

(i) $28 \mathrm{D}$ immersed the specimens in water for 27 days.

(ii) $7 \mathrm{D}$ cured the specimens in water for 6 days and then air-dried in the laboratory with $31 \pm 3^{\circ} \mathrm{C}$ temperature and $84 \pm 3 \%$ of relative humidity, until the age of testing.

(iii) AC kept the specimens in the laboratory environment.

\section{Results and Discussion}

3.1. Slump. The slump values of all the concrete mixes are indicated in Table 3. It was found that the control conventional concrete showed the highest workability of about $205 \mathrm{~mm}$. However, the partial substitution of OPS in CM consistently decreased the slump value. It was mainly because of the organic nature of OPS with many pores on the surface which resulted in high water absorption than the crushed granite aggregates as well as flaky shape of the OPS aggregates. Ahmad et al. [27] reported that it is essential to obtain the water absorption of the aggregates because aggregates may significantly reduce the concrete's workability and consistency.

Results show that the partial substitution of OPS up to $80 \%$ in the control NWC still shows good workability. As reported by Mehta and Monteiro [28], slump value for acceptable workability of LWAC ranges from 50 to $75 \mathrm{~mm}$.

3.2. Density. The compacted bulk density of conventional coarse aggregate is $40 \%$ higher than OPS coarse aggregate. 
TABLE 3: The slump value of all the mix proportions.

\begin{tabular}{lc}
\hline Mix code & Slump $(\mathrm{mm})$ \\
\hline CM & 205 \\
C20 & 130 \\
C40 & 90 \\
C60 & 70 \\
C80 & 65 \\
C100 & 40 \\
\hline
\end{tabular}

Therefore, the partial substitution of OPS in conventional concrete should significantly reduce the density with the average difference between the demoulded and oven-dry density of about $68 \mathrm{~kg} / \mathrm{m}^{3}$. In substitution levels of 0 to $40 \%$, the concretes can be considered as semi-lightweight concretes with the oven-dry density ranging from 2100 to $2200 \mathrm{~kg} / \mathrm{m}^{3}$. Abouhussien et al. [29] reported that the concretes with the density from 2000 to $2200 \mathrm{~kg} / \mathrm{m}^{3}$ are categorized as semi-lightweight. Results show that at 60, 80, and $100 \%$ replacement levels, the oven-dry density was about 2015,1988 , and $1900 \mathrm{~kg} / \mathrm{m}^{3}$, respectively. BS EN 206-1 [30] specified the LWC as a concrete with the oven-dry density from 800 to $2000 \mathrm{~kg} / \mathrm{m}^{3}$. Therefore, by replacing more than $60 \%$ of normal-weight aggregates with OPS, a lightweight aggregate concrete can be produced.

A linear relationship with strong correlation was achieved between the densities and the percentage of OPS substitution as shown in Figure 1. Compared to the density of NWC $\left(2337 \mathrm{~kg} / \mathrm{m}^{3}\right)$, there is a saving in self-weight of about 14,15 , and $19 \%$ for concretes with 60,80 , and $100 \%$ substitution of OPS, respectively. Figure 2 shows relationship between the 28-day compressive strength and the ovendry density. It was found that as the substitution level of OPS in conventional concrete increased, the density and the 28day compressive strength were constantly reduced and the linear equation with a very superior coefficient of determination $\left(R^{2}=0.99\right)$ value was found.

The regression statistics for obtained equations for six tests in Figures 1 and 2 are evaluated and shown in Tables 4 and 5 , respectively. In the model, linear parameters were significant with $p$ value $<0.05$. Any $p$ value smaller than 0.05 shows that the model is significant at the $95 \%$ confidence limit. In addition, if the $p$ value is less than 0.05 , it shows a that significant difference does exist between the tests, and the null hypothesis is rejected. If the $p$ value is larger than 0.05 , it means that a significant difference exists between the tests [31].

3.3. Compressive Strength under Standard Curing. The development of compressive strength for all mixes at 1, 3, 7, 28, 56, 90, and 120 days are shown in Figure 3. In all mixes, the compressive strength was increased with age. However, the results showed that with increasing the OPS incorporation level, the compressive strength of mixes was reduced. With the percentage replacement of 60,80 , and $100 \%$, the decrease in compressive strength at $1,3,7$, and 28 days was found in the range of $26-33 \%$ for C60, 35-47\% for C80, and $40-49 \%$ for C100 concrete mixes, respectively. Moreover, Basri et al. [32] stated that compressive strength of OPSC at 28 days was

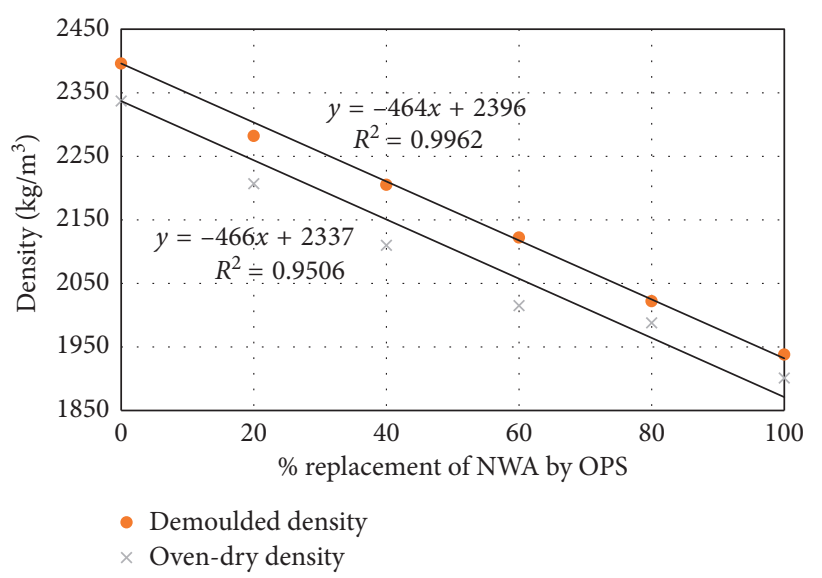

FIGURE 1: Relationship between the density and the substitution of OPS in NWC.

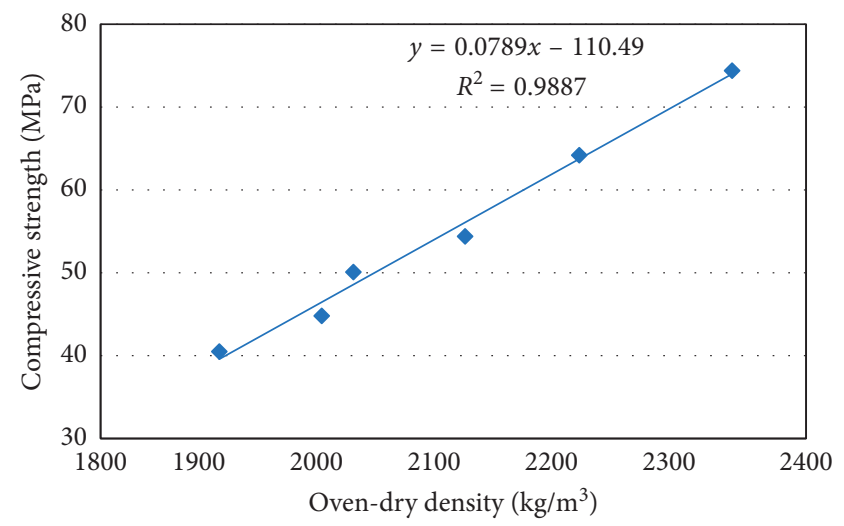

FIgURE 2: Relationship between 28-day compressive strength and the oven-dry density.

TABLE 4: Early-age and 28-day compressive strengths under continuous moist curing.

\begin{tabular}{lcccc}
\hline Mix code & 1 day & 3 days & 7 days & 28 days \\
\hline CM & $43(58 \%)$ & $55.6(75 \%)$ & $63.2(85 \%)$ & 74.4 \\
C20 & $36(56 \%)$ & $51.7(81 \%)$ & $56.1(87 \%)$ & 64.2 \\
C40 & $34(63 \%)$ & $44.7(82 \%)$ & $48.6(89 \%)$ & 54.4 \\
C60 & $32(64 \%)$ & $40.3(80 \%)$ & $44.2(88 \%)$ & 50.1 \\
C80 & $23(51 \%)$ & $36.6(80 \%)$ & $40.0(89 \%)$ & 44.8 \\
C100 & $22(54 \%)$ & $33.4(82 \%)$ & $36.3(90 \%)$ & 40.5 \\
\hline
\end{tabular}

Values in parenthesis present early-age compressive strength ratio to 28 days.

lower than conventional concrete by about $42-55 \%$, depending on the curing condition.

Obtained results show that the 28-day compressive strengths of all concretes containing OPS are comparable with structural LWC. Reduction on the compressive strength of OPS concrete is due to smooth surface texture of the OPS aggregates which resulted weaker interfacial zone [19, 33, 34]. Mannan et al. [33] investigated the compressive strength of OPSC. They reported that the main reason of the failure in this type of concrete is because of adhesion 
TABLE 5: Splitting tensile strength for all the mixes under continuous moist and air curing conditions.

\begin{tabular}{lccccc}
\hline \multirow{2}{*}{ Mix code } & \multicolumn{2}{c}{ Moist curing } & \multicolumn{2}{c}{ Air-drying } & Reduction in tensile strength under air-drying \\
& 1 day & 7 days & 28 days & 28 days & compared to moist curing (\%) at 28 days \\
\hline CM & $3.53(69 \%)$ & $3.85(75 \%)$ & 5.10 & 4.80 & 6.0 \\
C20 & $3.20(78 \%)$ & $3.50(85 \%)$ & 4.10 & 3.90 & 5.0 \\
C40 & $3.00(81 \%)$ & $3.50(95 \%)$ & 3.70 & 3.20 & 14.0 \\
C60 & $2.60(71 \%)$ & $3.40(93 \%)$ & 3.65 & 3.10 & 15.0 \\
C80 & $2.50(70 \%)$ & $3.30(94 \%)$ & 3.50 & 2.80 & 20.0 \\
C100 & $2.40(71 \%)$ & $3.20(94 \%)$ & 3.40 & 2.70 & 21.0 \\
\hline
\end{tabular}

Values in parenthesis present the early-age splitting tensile strength to 28 days under moist curing condition.

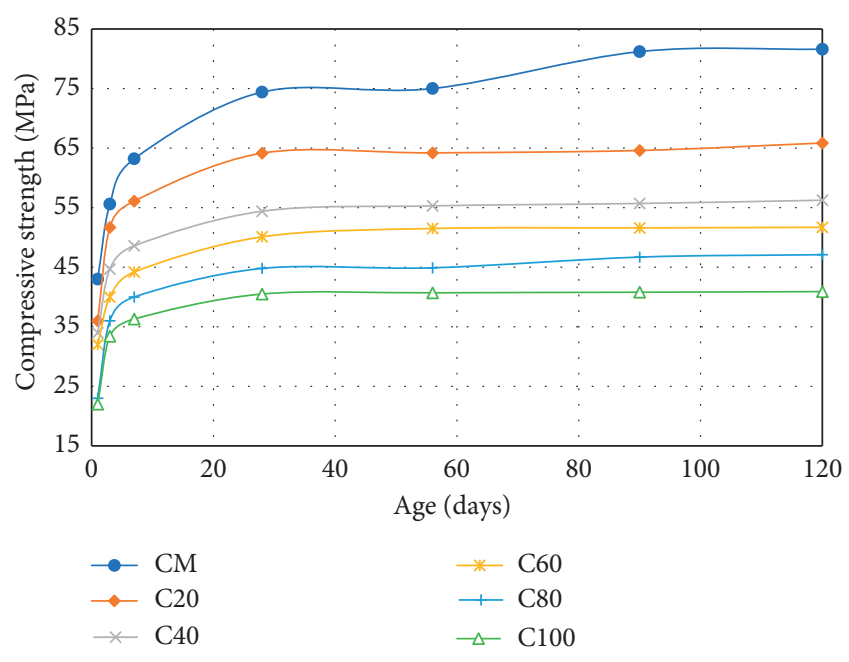

Figure 3: Compressive strength development of concrete mixes.

between the shells and the cement matrix. Some pretreatment techniques were introduced by them to enhance the quality of the shells in order to achieve high compressive strength of the concrete. Shafigh et al. [19] developed high-strength lightweight concrete (HSLC) using aged OPS as an aggregate with pretreatment techniques. They reported that use of aged OPS provided a stronger interfacial mechanical bond and as a result high 28-day compressive strength up to $48 \mathrm{MPa}$ with the oven-dry density less than $2000 \mathrm{~kg} / \mathrm{m}^{3}$.

The comparison of early ages and 28-day compressive strengths under full moist curing is shown in Table 4. It was determined that, by using OPS in NWC, all the mixes achieved $51-64 \%$ of their 28-day compressive strength at 1 day, $75-82 \%$ at the age of 3-day age, and $85-90 \%$ at 7 -day age. Fujji et al. [35] pointed out that 7 to 28 days compressive strength ratio is in the range of 80 to $90 \%$ for HSLC, whereas, in another study reported by Holm and Bremner [36], this ratio is between 80 and $90 \%$ for HSLC. However, for an artificial LWAC, the ratio of 7 to 28 days compressive strengths was found between 76 and 87\% [37]. Therefore, in the present research, it was found that the OPS lightweight concretes showed the similar 7 to 28 -day compressive strength ratios compared to the other types of structural lightweight aggregate concretes.

In structural engineering, the prediction models for 28day compressive strength from early ages are greatly required. For high-strength concretes, it is difficult to determine the specific prediction equation for the 28-day compressive strength because of the behavior and type of the aggregate [38]. The obtained relationship between compressive strength at 28-day and premature early age at 1,3 , and 7 days is indicated in Figure 4. The linear prediction models were made for all mixes to compute the 28-day compressive strength from the early ages. It was found that all the prediction models for early ages showed satisfactory reliability with $R^{2}>90$. Furthermore, statistics analysis for the estimated relationships, which was obtained from six observations in each curing condition (shown in Figure 4), confirmed that the regression model is significant.

\subsection{Compressive Strength under Partially Early Curing.} Curing of concrete is a process to keep moisture and temperature in concrete during its initial stages to confirm that it develops its desired properties [39]. In Figure 5, the comparison of the 28-day compressive strength of the mixes under 7-day water curing (7D), 28-day water curing, and air-curing/drying (AC) is illustrated. From this figure, almost similar compressive strength can be observed for the mixes containing OPS from 20 to $60 \%$ (semilightweight concrete) under 7 - and 28-day curing conditions. However, as the substitution level of OPS exceeds $60 \%$, the compressive strength reduced under $7 \mathrm{D}$ curing condition with the average difference of about $7 \%$ compared to continuous moist-cured specimens $(28 \mathrm{D})$. Whereas generally under AC condition, compressive strength of the mixes was reduced, compared to $7 \mathrm{D}$ moistcured specimens. Control concrete showed the lowest reduction in compressive strength under AC condition. However, as the substitution level of OPS increased, the reduction in compressive strength also increased. All concretes containing OPS showed the average reduction of about $9 \%$ under AC condition compared to the $7 \mathrm{D}$ cured specimens. Therefore, for OPS concrete, at least 7 days of moist curing is essential to develop compressive strength properly. Mehta and Monteiro [28] also pointed out that minimum 7 days of moist curing is required for the concretes containing ordinary Portland cement.

As can be seen in Figure 5, a reduction of the 28-day compressive strength was observed for all the specimens cured under air-drying condition (AC). Compared to continuous moist curing $(28 \mathrm{D})$, the $\mathrm{C} 20$ and C40 mixes showed almost similar ratio (about 9\%) of reduction in compressive strength compared to the CM. However, as the substitution level of OPS increased from $40 \%$, the reduction 


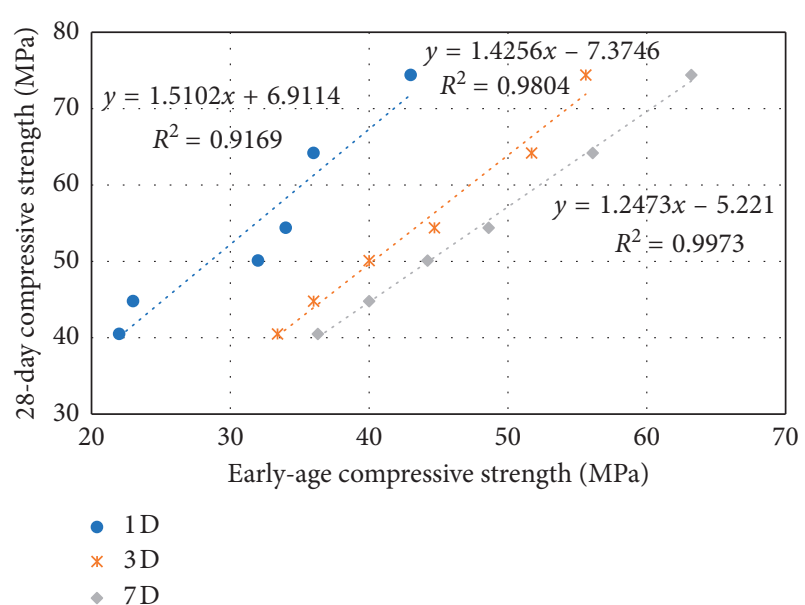

FIGURE 4: Relationship between the early-age (1, 3, and 7 days) and 28-day compressive strength for mixes.

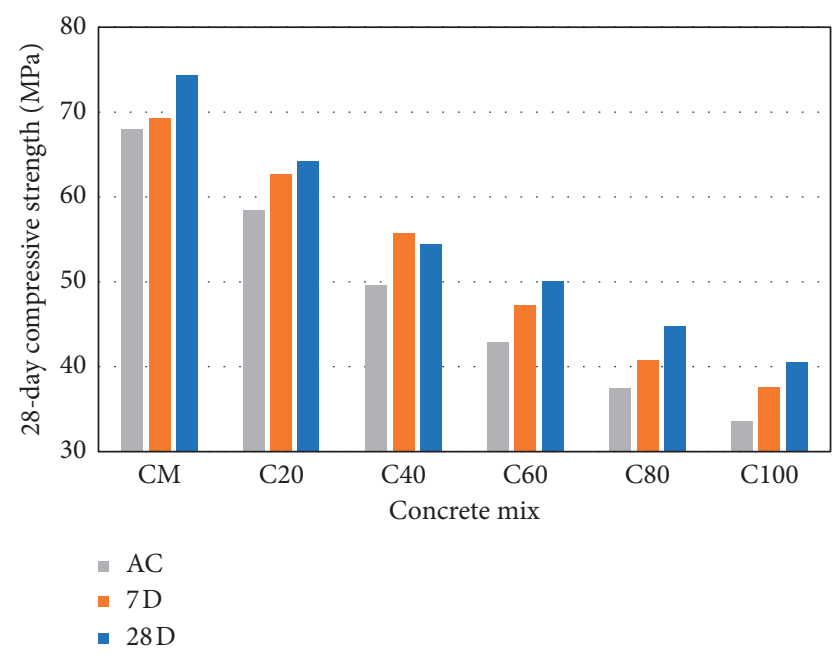

FIGURE 5: 28-day compressive strength under different curing conditions.

in compressive strength also significantly increased. With the substitution of 60,80 , and $100 \%$ of OPS aggregate in NWC, the compressive strength value was reduced by $14 \%$, $16 \%$, and $17 \%$, respectively.

The obtained prediction model between continuous moist and air-drying curing condition for all concretes (NWA-OPS) at 28 days of compressive concrete is demonstrated in Figure 6. This relationship was also proposed by previous researchers for NWC containing silica fume (NCSF) and OPS concrete made by fly ash (OPS-FA) $[39,40]$. It was noted that the prepared concretes in this study (NWAOPS) showed better compressive strength under AC condition than NC-SF and OPS-FA concretes.

Obtained regression statistics for the relationship between compressive strength of NWA-OPS mixes with and without curing (five samples) in Figure 6 show that the model of regression is significant.

3.5. Splitting Tensile Strength. Basically, to address the issue of low tensile strength of concrete, designers consider steel

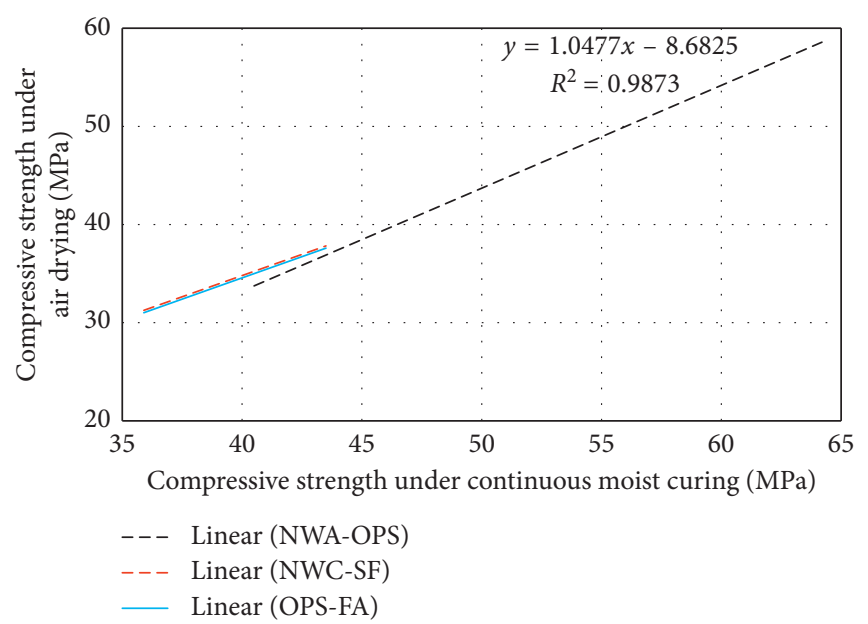

FIGURE 6: The relationship between compressive strength of NWAOPS mixes with and without curing and comparison with normal concrete containing silica fume (NC-SF) [40] and OPS concrete containing fly ash (OPS-FA) [41].

reinforcement in their designs in order to increase the tensile capacity of the concrete structures. Whereas for some structures such as airfield slabs, highways, concrete pavements, and dams, employing the reinforced concrete is impractical. Therefore, it is quite necessary to select a trustworthy splitting tensile strength value of the concrete, particularly for plain concrete structures such as dams under seismic behavior [28, 42]. Furthermore, it was reported by Bhanja and Sengupta [43] that if the concrete has low tensile strength, cracks under tension regions may affect serviceability and durability of the concrete structure.

The splitting tensile strength for all the mixes under moist curing at different ages and under air-drying at the age of 28-day is shown in Table 5. As shown in this table, the values of splitting tensile strengths for all the mixes are more than $2 \mathrm{MPa}$ at 1-day age, and it gradually increased with the increment of the compressive strength. According to ASTM C 330 [44], for the structural grade of LWC, $2.0 \mathrm{MPa}$ is the minimum value of the splitting tensile strength.

The control mix CM achieved 75\% splitting tensile strength of its 28-day strength. Whereas by incorporating OPS from 20 to $100 \%$, all the mixes achieved more splitting tensile strength at early ages. Furthermore, Table 5 also presents the comparison of splitting tensile strength under continuous moist curing and air-drying conditions. Results show that if the OPS content in concrete exceeds $20 \%$, significant reduction on the tensile strength can be observed in concrete under air-drying condition.

Figure 7 shows a relationship between the incorporation level of OPS and the splitting tensile strength of concrete with normal coarse aggregate. This figure indicates that as the substitution level of OPS increased, the splitting tensile strength decreased at all ages. Concrete containing 100\% coarse OPS aggregate has a splitting tensile strength more than $2 \mathrm{MPa}$ which shows that it has standard requirement in term of tensile strength, although this value for concretes containing OPS is less than control mix. As can be seen from 


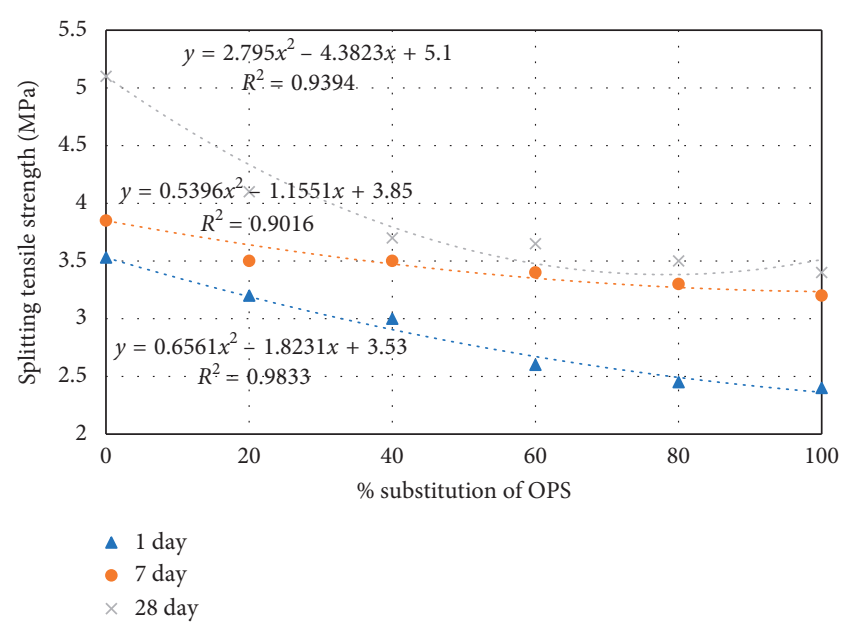

FIgURE 7: Relationship of splitting tensile strength and OPS substitution level for all mixes.

the regression analysis for predicted relationships in Figure 7 (for six observations in each curing condition), the calculated equations are reliable. For mixes $\mathrm{C} 60$ to $\mathrm{C} 80$ which are categorized as lightweight concrete, the ratio of 28-day splitting tensile strength to the compressive strength is on average $8 \%$. However, this ratio for NWC is generally from 8 to $14 \%[18,45]$. Therefore, the prepared lightweight concretes can still be considered as good quality concrete with the ratio of splitting tensile to compressive strength similar to the NWC.

The comparison of splitting tensile test results with the predicted results from different proposed models by various researchers and standards is shown in Figure 8. Shafigh et al. [18] proposed equation (1) for the LWC produced by using solid wastes from the palm oil industry. Arioglu et al. [46] proposed equation (2) for the NWC with a cylinder compressive strength in the range of 40$120 \mathrm{MPa}$. ACI Committee [47] proposed equation (3) for the NWC with a cylinder compressive strength ranging from 21 to $83 \mathrm{MPa}$. For OPSC with cube compressive strength in the range of 35 to $53 \mathrm{MPa}$, equation (4) was proposed [48], whereas equation (5) was presented for NWC [49]. Shafigh et al. [8] proposed equation (6) for OPSC containing original OPS aggregates with cube compressive strength from 17 to $37 \mathrm{MPa}$. Neville [42] reported equation (7) for pelletized blast furnace slag LWAC, with cube compressive strength in the range of 10 to $65 \mathrm{MPa}$. For LWAC containing cold-bonded fly ash with cube compressive strength between 20 and $47 \mathrm{MPa}$, equation (8) was proposed by Gesoglu et al. [50]. Smadi and Migdady [51] studied the natural tuff LWA concrete with high compressive strength and proposed equation (9) for prediction of the splitting tensile strength. Whereas equation (10) was made for high-strength lightweight concrete [52].

$$
\begin{aligned}
& f_{\mathrm{t}}=0.27\left(f_{\mathrm{cu}}\right) 0.63, \\
& f_{\mathrm{t}}=0.387\left(f_{\mathrm{cy}}\right) 0.63,
\end{aligned}
$$

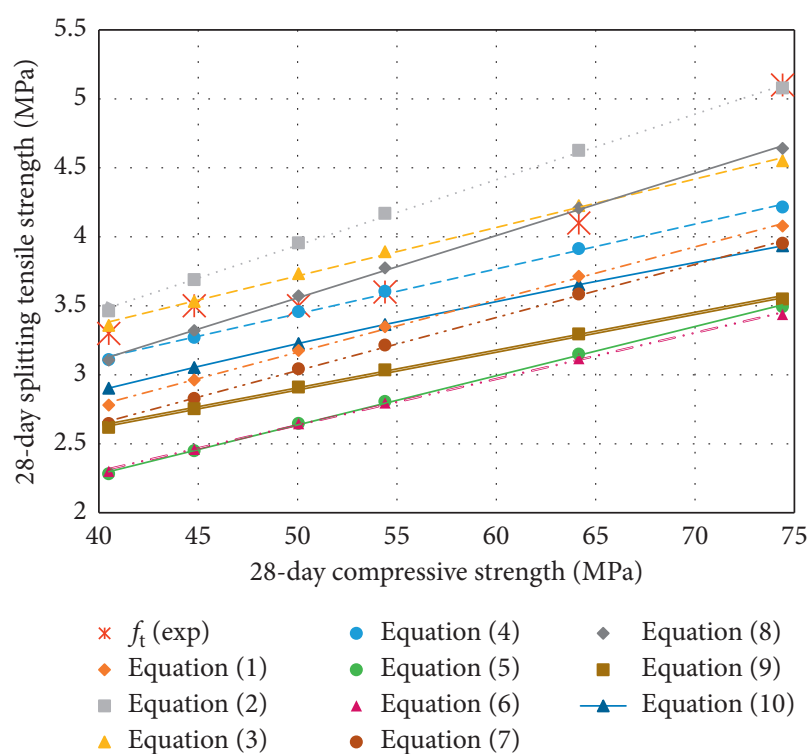

FIGURE 8: Experimental and theoretical splitting tensile strength of all concrete mixes.

$$
\begin{aligned}
& f_{\mathrm{t}}=0.59\left(f_{\mathrm{cy}}\right) 0.5, \\
& f_{\mathrm{t}}=0.4887 \sqrt{f_{\mathrm{cu}}}, \\
& f_{\mathrm{t}}=0.20\left(f_{\mathrm{cy}}\right) 0.70, \\
& f_{\mathrm{t}}=0.20 \sqrt[3]{f_{\mathrm{cu}}^{2}}, \\
& f_{\mathrm{t}}=0.23 \sqrt[3]{f_{\mathrm{cu}}^{2}}, \\
& f_{\mathrm{t}}=0.27 \sqrt[3]{f_{\mathrm{cu}}^{2}}, \\
& f_{\mathrm{t}}=0.46 \sqrt{f_{\mathrm{cy}}}, \\
& f_{\mathrm{t}}=0.51 \sqrt{f_{\mathrm{cy}}},
\end{aligned}
$$

where $f_{\mathrm{t}}$ is the splitting tensile strength and $f_{\mathrm{cu}}$ and $f_{\mathrm{cy}}$ are the cube and cylindrical compressive strengths, respectively. As shown in Figure 8, some of the equations such as equations (3) and (8) present forecast results close to the experimental results, with $90 \%$ reliability.

3.6. Water Absorption. The water absorption test was carried out for all concrete mixes at the age of 28 days for 30 minutes (initial water absorption) and 72 hours (final water absorption), as shown in Figure 9. Normal-weight concrete mixture (CM) showed the initial water absorption less than $3 \%$. However, as NWA was replaced with OPS aggregate, the water absorption was consistently increased due to high water absorption of the OPS aggregate. As can be seen in Table 1, compared to crushed granite, the water absorption 


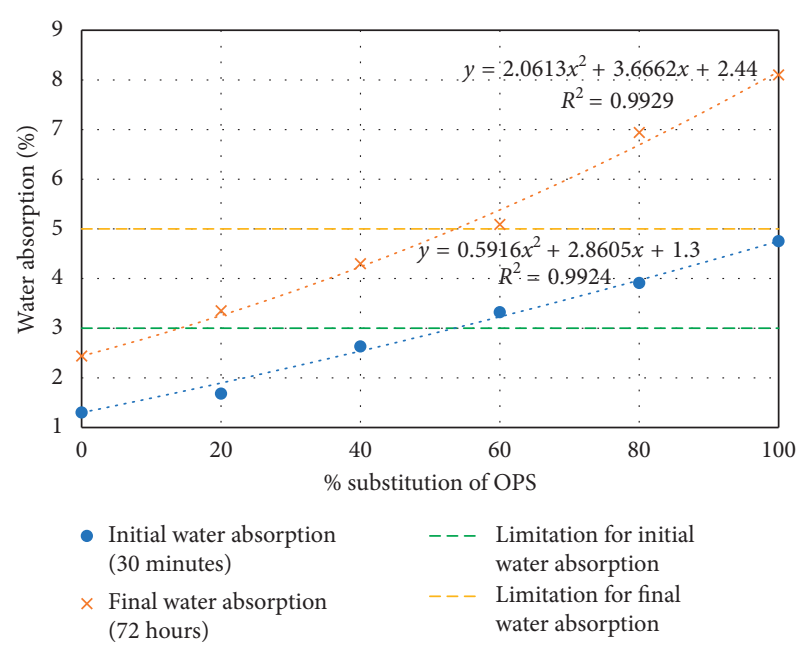

FIgURE 9: Relationship between OPS content in NWC and water absorption.

of the OPS aggregate is significantly higher. Teo et al. [53] concluded in his report that the water absorption of normal strength OPS concretes is higher than $10 \%$. Whereas other types of structural LWACs like pumice and expanded polystyrene aggregate concrete have the water absorption ranging from $14 \%$ to $22 \%$ and from 3 to $6 \%$, respectively $[54,55]$. The investigations on analysis of statistics for six samples showed that the predicted models in Figure 9 are trustworthy.

The quality of concrete is categorized as good, average, and poor based on the initial water absorption values of $0-3 \%, 3-5 \%$, and above $5 \%$, respectively [56]. It has been specified that a good quality concrete has final water absorption less than $5 \%$. Based on the mentioned criteria, it can be concluded that incorporation of OPS as coarse aggregate in concrete should be less than $50 \%$ of total volume of coarse aggregate.

3.7. Drying Shrinkage Development. For structural members, the drying shrinkage strain of the concrete plays a very important role and is possibly harmful when it is restrained. However, it is not critical when used for insulation or filling purposes [57]. Reports [42, 58] show that the LWC has higher drying shrinkage than NWC. It is mainly influenced by volume of aggregate as well as aggregate's properties. In these reports, the impact of partial substation of crushed granite with OPS on concrete's drying shrinkage was investigated under cured and uncured conditions.

3.7.1. Drying Shrinkage of Uncured Specimens. Drying shrinkage development of concrete mixes under air-drying condition up to 275 days of age is presented in Figure 10. To evaluate precise value of the drying shrinkage strain, two test specimens for each mix were prepared, and the average of the results was applied for analysis. Control concrete (CM) showed the long-term shrinkage strain of 318 microstrain, which is significantly lower than the other mixes. Generally, normal-weight concrete showed the

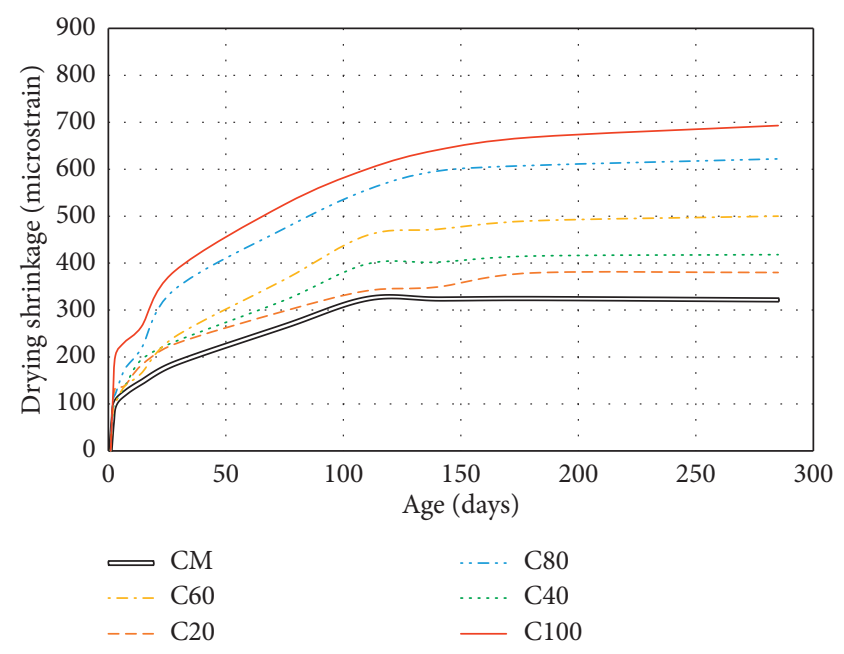

FIgURE 10: Development of drying shrinkage of all concrete mixes under air-drying condition.

drying shrinkage ranging from of 200-800 microstrain [59]. It was noted that the OPS's incorporation in conventional concrete consistently increased the drying shrinkage strain of the mixes. As shown in Figure 10, at the age of 7 days, the contribution of OPS up to $60 \%$ in NWC (C20 to C60) has shown similar drying shrinkage results to the CM. However, as the substitution level increased beyond $60 \%$ (C80 \& C100 mixes), the significant increase for shrinkage strain was observed even after 2 days of drying. During the first 28 days, the increasing rate of shrinkage strain for mixes C20 to C60 was found to be moderate compared to the CM mix. The average difference between the mixes was found to be about $21 \%$. However, this ratio was considerably higher for mixes C80 and C100 which is about $47 \%$ and $52 \%$, respectively, higher compared to control conventional concrete. After 4 months, the drying shrinkage values for CM to $\mathrm{C} 60$ mixes were found constant. However, the C80 and C100 mixes were showing the consistent increase in the shrinkage strain at the similar ages. After around 10 months, the C20, C40, C60, C80, and C100 mixes showed about $16 \%, 24 \%, 36 \%, 49 \%$, and $54 \%$, higher drying shrinkage strain against the CM, respectively.

The surface texture and shape of OPS aggregates are the key factors for higher drying shrinkage of concrete containing OPS. Basically, Surface texture of the crushed granite is rough which provides a strong bond with the cement matrix. In contrast, OPS aggregates are flaky and smooth in the surface texture. Therefore, by the blend of both NWA and OPS aggregate in concrete, higher drying shrinkage strain is expected. Al-Attar [60] studied the shrinkage behavior of conventional concrete by considering crushed and uncrushed gravel aggregate. He highlighted that the drying shrinkage of concrete using uncrushed gravel aggregates with smooth texture was higher than concrete made with crushed aggregates. Aslam et al. [61] investigated the drying shrinkage behavior of blended coarse LWAC. They reported that drying shrinkage of the OPSC could be decreased significantly by 
contribution of rough surface textured oil-palm-boiler clinker (OPBC) aggregate in OPS concrete.

Another important factor that affects the drying shrinkage of concrete is the type of aggregate and its stiffness. Normally, elastic modulus of NWC is in the range of 14 to $41 \mathrm{GPa}$ [18]. However, elastic modulus of OPSC was found much lower compared to the NWC, in the range of 5.3 to $10.9 \mathrm{GPa}$ [5]. Neville [62] revealed that modulus of elasticity of concrete depends on the elastic modulus of its constituents and their proportions by volume in concrete. Therefore, it can be confirmed that use of OPS in conventional concrete significantly decreased the elastic modulus of the concrete due to the low elastic moduli of OPS aggregate. On the other hand, it should be noted that concrete containing aggregate with low modulus of elasticity has higher shrinkage strain compared to conventional aggregate concrete [42]. It was pointed out by Shafigh et al. $[48,63]$ that the expanded clay lightweight aggregate concrete with about $30 \%$ lower compressive strength than OPS concrete showed approximately $40 \%$ greater modulus of elasticity. Therefore, in this research, it was expected that by using of OPS in NWC, the elastic moduli of concrete reduced which resulted higher drying shrinkage strain for concrete.

Another cause of high concrete's drying shrinkage is the moisture content of aggregates. Al-Attar [60] revealed that the use of the dry aggregate in concrete mixture resulted lower drying shrinkage compared to saturated aggregates. In this research, crushed granite aggregates were replaced with saturated OPS aggregates, and therefore, it is expected that concrete containing higher saturated OPS aggregates show higher drying shrinkage.

Based on the result presented in Figure 10, it is recommended that in concretes under air-drying condition, incorporation of OPS should be limited to $60 \%$ of total volume of coarse aggregate.

3.7.2. Drying Shrinkage of Cured Specimens. To control initial cracks and shrinkage, the adequate duration of curing plays an important role in concrete [64]. At the early ages, a proper long period of curing significantly improves the efficiency of materials. Also, it can postpone and reduce the long-term drying shrinkage. In Figures 11 and 12, the growth of drying shrinkage for all concrete mixes under 7 and 28 days curing is indicated. As shown in Figure 11, the control conventional concrete showed drying shrinkage of about 270 microstrain at later ages which was significantly low (on average 64\%) compared to the C80 and C100 mixes with the shrinkage strain in the range of 700-800 microstrain. However, at long-term ages, the C20, C40, and C60 mixes showed greater drying shrinkage strain of about $20 \%$, $38 \%$, and $49 \%$, respectively, in comparison with CM under 7 days of moist curing. Compared to the air-dried conditions, 7 -day moist-cured specimens showed on average about 5\% lower drying shrinkage results at early ages. Similarly, the progress of drying shrinkage strain under 28-day moist curing is shown in Figure 12. At the early ages, all the mixes showed the similar trend for 7-day moist-cured specimens

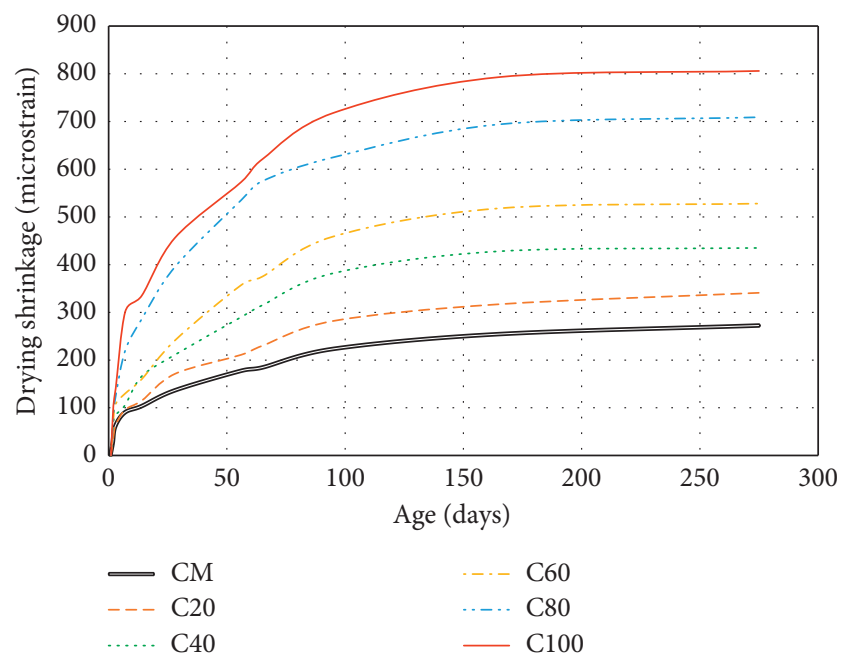

FIGURE 11: Development of drying shrinkage strain under 7-day moist curing.

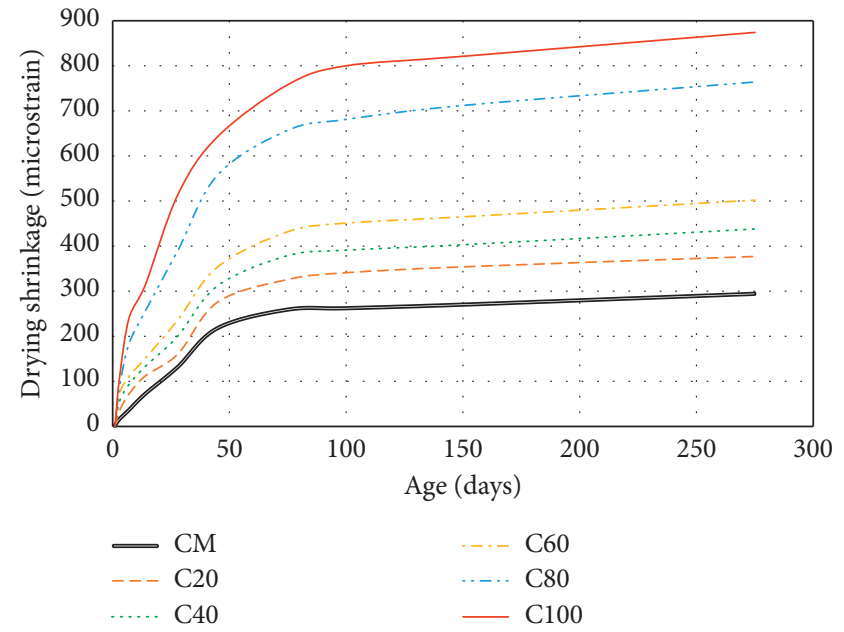

FIGURE 12: Development of drying shrinkage strain under 28-day moist curing.

with consistent increment in shrinkage. At long-term age (275 days), higher drying shrinkage of about $33 \%$ was recorded for concrete mixes containing OPS up to $60 \%$, compared to the CM. Whereas for mixes containing OPS beyond $60 \%$, the increment in shrinkage was significantly higher (about 64\%). Shrinkage values of CM to C60 mixes were found almost constant after 75 days. However, the constant trend for same mixes was observed at about 110 days of age for the 7-day moist-cured specimens. Nilsen and Aitcin [65] measured the drying shrinkage of low-density concrete made of expanded shale aggregate and reported a shrinkage value of 160 microstrain at about 4 months of age under 7-day moist curing. Few years later, Al-Khaiat and Haque [66] studied the drying shrinkage behavior of lytag LWC under 7-day moist curing and reported a long-term (3 months) drying shrinkage value of about 640 microstrain. They concluded that the type of lightweight aggregate in the mixture directly affects the drying shrinkage. Furthermore, Kayali et al. [67] reported the value of shrinkage about 450 
microstrain at 90 days for lightweight sintered fly ash aggregate concrete. They also showed that shrinkage of NWC was constant and stable after 400 days, while for LWC after a same period of drying, shrinkage had an upward trend. Aslam et al. [3] studied the impact of lightweight aggregate type on concrete's drying shrinkage. They reported that LWAC mixes containing OPS and OPBC showed lower drying shrinkage in comparison with structural LWCs made of expanded shale, lytag, and sintered fly ash. Concrete mixes containing $20-60 \%$ of OPS showed drying shrinkage in the range of 280-450 and 350-460 microstrain for 7-day and 28day cured specimens, respectively, at 90 days of age. These ranges are lower compared to the lightweight concretes made with expanded shale, lytag, and sintered fly ash. However, the C80 and C100 mixes showed remarkably higher drying shrinkage against the same concretes at the same ages.

\subsubsection{Comparison between Different Curing Conditions.} From the previous studies, it was found that curing has significant effect on reduction of crack and shrinkage of concrete $[68,69]$. Oliveira et al. [70] indicated that the curing could control drying of concrete which causes delaying effect in the shrinkage as well as allowing the natural growth of concrete's mechanical properties. Therefore, two different curing conditions were considered in this study to evaluate the drying shrinkage of concrete samples in order to control the drying process of concrete. The relationship between airdried and moist-cured specimens at early ages for drying shrinkage is given in Table 6. It was observed that under 7day moist curing, the CM to $\mathrm{C} 60$ mixes showed a reduction in drying shrinkage at early ages. Whereas the C80 and C100 mixes showed higher drying shrinkage than air-dried specimens. This was mainly because of high volume of OPS aggregates. Table 6 shows the effect of curing as well as curing period which is essential to control drying shrinkage of concrete specially at early ages. In general, more curing time results lower drying shrinkage. However, the impact of curing period on short-term drying shrinkage was more significant on concretes containing less volume of OPS. Concrete containing 80 to $100 \%$ coarse OPS aggregate showed high drying shrinkage under both 7- and 28-day moist curing conditions.

West [71] pointed out that if there is not enough moisture for curing, existing moisture is consumed due to hydration process, and shrinkage would occur. Furthermore, inadequate water on concrete's surface caused more shrinkage and crack.

The long-term drying shrinkage under different curing conditions for all the mixes is shown in Table 7 . It is found that the CM had the lowest drying shrinkage results among the mixes under both curing conditions compared to airdried specimens. The consistent reduction in shrinkage was also observed for concretes with low substitution of OPS up to $40 \%$ (C20 \& C40 mixes). Furthermore, on average, the C80 and C100 mixes showed higher shrinkage strain under both 7 - and 28-day moist curing conditions of about $16 \%$ and $25 \%$, respectively, compared with air-dried specimens.
Neville [72] reported that the shrinkage at early ages was delayed by long-term moist curing. However, the magnitude of shrinkage will be higher at later ages. Furthermore, Carlson [64] specified the contrary influences of long-term moist curing. Firstly, it increases the hardness of cement matrix which improves the restraining effect against the shrinkage. Secondly, it initiates more hydrated cement which causes higher drying shrinkage strain. Some other studies [28, 42] revealed that after curing, in case of low relative humidity, diminution in volume would occur due to the force generated by moisture migration from the materials. Similarly, the increased moisture of material could cause the swelling. Aslam et al. [3] investigated the drying shrinkage behavior of structural LWAC under 7-day moist curing. They highlighted that the saturated aggregates in the concrete mixes could minimize the early-age drying shrinkage and postpone it; nonetheless, higher shrinkage was recorded in long term. Bogas et al. [73] compared the behavior of lightweight and conventional concretes under 7day moist curing. It was concluded that the long-term shrinkage could be reduced and delayed by proper curing, by about $16.5 \%$ for lightweight and $12 \%$ for conventional concretes. Furthermore, they specified that the long-term shrinkage should be considered for low-density concrete due to its slow drying process.

\section{Conclusion}

In this research, in order to achieve the optimum level of oil palm shell (OPS) contribution in concrete mixture for production of the lightweight aggregate concrete, six concrete mixes with different level of OPS as replacement of crushed granite from 20 to $100 \%$ (by volume) with interval of $20 \%$ were produced. The obtained results of the mechanical properties and drying shrinkage are represented as follows:

(1) Replacement level of OPS from 60 to $100 \%$ in normal-weight concrete transformed it into lightweight concrete, whereas concrete mixes containing 20 to $60 \%$ of OPS aggregate, with oven-dry density between 2100 and $2200 \mathrm{~kg} / \mathrm{m}^{3}$ are categorized as semi-lightweight aggregate concretes.

(2) In improper curing condition, concrete containing OPS aggregates has higher loss of compressive strength compared to conventional aggregate concrete. Under partial early curing (7D), concretes containing OPS showed 9\% higher compressive strength in comparison with air-drying curing condition (AC). At least 7 days of moist curing is recommended for OPS concrete.

(3) Control mix (CM) showed the initial water absorption lower than 3\%. However, since normalweight aggregate was replaced with OPS aggregate, the water absorption was consistently increased. In order to achieve a good quality concrete with final water absorption less than 5\%, incorporation of OPS as coarse aggregate in concrete should be less than $50 \%$ of the total volume of coarse aggregate. 
TABLE 6: Effect of curing at early ages on the drying shrinkage.

\begin{tabular}{|c|c|c|c|c|c|c|c|c|c|c|c|}
\hline \multirow{4}{*}{$\begin{array}{l}\text { Mix } \\
\text { cods }\end{array}$} & \multicolumn{9}{|c|}{ Drying shrinkage $\left(\times 10^{-6}\right)$} & \multirow{4}{*}{$\begin{array}{c}\text { Compared } \\
\text { average } \\
\text { (7 days) } \\
(\%)\end{array}$} & \multirow{4}{*}{$\begin{array}{c}\text { Compared } \\
\text { average } \\
\text { (28 days) } \\
(\%)\end{array}$} \\
\hline & \multirow{2}{*}{\multicolumn{3}{|c|}{$\begin{array}{c}\text { Uncured } \\
\text { Age (days) }\end{array}$}} & \multirow{2}{*}{\multicolumn{3}{|c|}{$\begin{array}{c}\text { Cured (7 days) } \\
\text { Age (days) }\end{array}$}} & \multirow{2}{*}{\multicolumn{3}{|c|}{$\begin{array}{c}\text { Cured (28 days) } \\
\text { Age (days) }\end{array}$}} & & \\
\hline & & & & & & & & & & & \\
\hline & 3 & 7 & 14 & 3 & 7 & 14 & 3 & 7 & 14 & & \\
\hline CM & 100 & 121 & 144 & $60(-40 \%)$ & $89(-26 \%)$ & $102(-29 \%)$ & $15(-85 \%)$ & $35(-71 \%)$ & $71(-51 \%)$ & -32 & $-69 \%$ \\
\hline $\mathrm{C} 20$ & 134 & 139 & 182 & $64(-52 \%)$ & $96(-31 \%)$ & $115(-37 \%)$ & $35(-74 \%)$ & $72(-48 \%)$ & $112(-38 \%)$ & -40 & $-54 \%$ \\
\hline $\mathrm{C} 40$ & 104 & 137 & 194 & $85(-18 \%)$ & $106(-23 \%)$ & $166(-14 \%)$ & $56(-46 \%)$ & $93(-32 \%)$ & $133(-31 \%)$ & -18 & $-37 \%$ \\
\hline C60 & 103 & 138 & 165 & $108(+05 \%)$ & $130(-06 \%)$ & $160(-03 \%)$ & $73(-29 \%)$ & $111(-20 \%)$ & $151(-8 \%)$ & -01 & $-19 \%$ \\
\hline C80 & 121 & 174 & 218 & $125(+03 \%)$ & $220(+26 \%)$ & $286(+31 \%)$ & $89(-26 \%)$ & $183(+05 \%)$ & $256(+17 \%)$ & +20 & $-01 \%$ \\
\hline $\mathrm{C} 100$ & 203 & 232 & 264 & $141(-31 \%)$ & $301(+30 \%)$ & $335(+27 \%)$ & $110(-46 \%)$ & $240(+03 \%)$ & $314(+19 \%)$ & +09 & $-08 \%$ \\
\hline
\end{tabular}

+ represents the positive shrinkage development in cured specimens in comparison with uncured specimens; - represents the negative shrinkage development in cured specimens in comparison with uncured specimens.

Table 7: Effect of curing on long-term drying shrinkage.

\begin{tabular}{|c|c|c|c|c|c|c|c|c|c|c|c|}
\hline \multirow{4}{*}{$\begin{array}{l}\text { Mix } \\
\text { cods }\end{array}$} & \multicolumn{9}{|c|}{ Drying shrinkage $\left(\times 10^{-6}\right)$} & \multirow{4}{*}{$\begin{array}{c}\text { Compared } \\
\text { average } \\
(7 \text { days }) \\
(\%)\end{array}$} & \multirow{4}{*}{$\begin{array}{c}\text { Compared } \\
\text { average } \\
\text { (28 days) } \\
(\%)\end{array}$} \\
\hline & \multirow{2}{*}{\multicolumn{3}{|c|}{$\begin{array}{l}\text { Uncured } \\
\text { Age (days) }\end{array}$}} & \multirow{2}{*}{\multicolumn{3}{|c|}{$\begin{array}{c}\text { Cured (7 days) } \\
\text { Age (days) }\end{array}$}} & \multirow{2}{*}{\multicolumn{3}{|c|}{$\begin{array}{c}\text { Cured ( } 28 \text { days) } \\
\text { Age (days) }\end{array}$}} & & \\
\hline & & & & & & & & & & & \\
\hline & 28 & 100 & 275 & 28 & 100 & 275 & 28 & 100 & 275 & & \\
\hline $\mathrm{CM}$ & 183 & 321 & 318 & $135(-26 \%)$ & $222(-31 \%)$ & $271(-15 \%)$ & $131(-28 \%)$ & $261(-19 \%)$ & $293(-08 \%)$ & -24 & -18 \\
\hline $\mathrm{C} 20$ & 227 & 341 & 380 & $171(-25 \%)$ & $282(-17 \%)$ & $341(-10 \%)$ & $161(-29 \%)$ & $341(0 \%)$ & $377(-01 \%)$ & -17 & -10 \\
\hline $\mathrm{C} 40$ & 232 & 398 & 418 & $211(-09 \%)$ & $382(-4 \%)$ & $435(+04 \%)$ & $201(-13 \%)$ & $391(-02 \%)$ & $438(+5 \%)$ & -03 & -03 \\
\hline $\mathrm{C} 60$ & 242 & 459 & 500 & $21(0 \%)$ & $459(0 \%)$ & $528(+06 \%)$ & $237(-02 \%)$ & $451(-02 \%)$ & $502(0 \%)$ & +02 & -01 \\
\hline $\mathrm{C} 80$ & 343 & 556 & 622 & $395(+15 \%)$ & $625(+12 \%)$ & $709(+14 \%)$ & $391(+14 \%)$ & $681(+22 \%)$ & $764(+23 \%)$ & +14 & +20 \\
\hline $\mathrm{C} 100$ & 382 & 600 & 693 & $456(+19 \%)$ & $718(+20 \%)$ & $806(+16 \%)$ & $515(+35 \%)$ & $800(+33 \%)$ & $874(+26 \%)$ & +18 & +31 \\
\hline
\end{tabular}

+ represents the positive shrinkage development in cured specimens in comparison with uncured specimens; - represents the negative shrinkage development in cured specimens in comparison with uncured specimens.

(4) Under air-drying curing condition and up to 275 days of age, CM showed the long-term shrinkage strain of 318 microstrain, while drying shrinkage consistently increased by incorporation of OPS in conventional concrete up to 693 microstrain for the mix containing just OPS as coarse aggregate. Almost similar drying shrinkage at early age (7 days) was obtained with contribution of OPS up to $60 \%$ in normal-weight concrete (CM). However, the significant increase in shrinkage strain was observed even after 2 days of drying for concrete mixes containing 80 and $100 \%$ OPS. At later ages (around 10 months), the mixes containing $20,40,60,80$, and $100 \%$ OPS showed about $16 \%, 24 \%, 36 \%, 49 \%$, and $54 \%$ higher drying shrinkage strain compared to the control mix, respectively.

(5) It is recommended that in concretes under air-drying condition, incorporation of OPS as coarse aggregate should be limited to $60 \%$ of total volume of the coarse aggregate in concrete mixture. Mixes containing coarse OPS more than $60 \%$ have high drying shrinkage and therefore they are not recommended to be used in structural elements.

(6) Under moist curing condition and up to 275 days of age, CM showed the shrinkage strain of 270 microstrain compared to the mixes containing 80 and $100 \%$ OPS lightweight concretes with the shrinkage strain in the range from 700 to 800 microstrain. Compare to air-dried conditions, 7-day moist-cured specimens showed on average about $5 \%$ lower drying shrinkage results at early ages, whereas at later ages, the average difference was not significant (about 2\%). However, under 28-day moist curing condition, mixes containing 80 and $100 \%$ OPS showed remarkably greater drying shrinkage in comparison with the same concretes at the same ages but under 7-day moist curing condition.

(7) Up to $60 \%$ replacement of crushed granite aggregates with OPS, structural lightweight aggregate concrete with maximum drying shrinkage strain of approximately 500 microstrain can be produced which is still in allowable limit for drying shrinkage.

(8) The conventional control concrete showed lowest drying shrinkage results among the mixes under both 7 - and 28-day moist curing conditions compared to air-dried specimens.

(9) For low substitution levels of OPS (up to 40\%), consistent reduction in drying shrinkage was observed when concrete specimens were cured. However, the difference between moist-cured and air-dried specimens reached to almost zero percent for the mix containing $60 \%$ OPS. The mixes containing 80 and $100 \%$ OPS showed higher shrinkage strain under both moist curing conditions of about $14 \%$ and $20 \%$, respectively, compared to air-dried specimens. 


\section{Data Availability}

The authors confirm that the data supporting the findings of this study are available within the article; however, further details are available from the corresponding author upon request.

\section{Conflicts of Interest}

The authors declare no conflicts of interest.

\section{Acknowledgments}

The authors would like to thank Vahid Alimohammadi for his help on this study. The authors gratefully acknowledge the financial support from the University of Malaya for the research grant no. PG116-2015A.

\section{References}

[1] V. Alimohammadi, M. Sedighi, and E. Jabbari, "Experimental study on efficient removal of total iron from wastewater using magnetic-modified multi-walled carbon nanotubes," Ecological Engineering, vol. 102, pp. 90-97, 2017.

[2] M. Batayneh, I. Marie, and I. Asi, "Use of selected waste materials in concrete mixes," Waste Management, vol. 27, no. 12, pp. 1870-1876, 2007.

[3] M. Aslam, P. Shafigh, and M. Z. Jumaat, "Oil-palm byproducts as lightweight aggregate in concrete mixture: a review," Journal of Cleaner Production, vol. 126, pp. 56-73, 2016.

[4] R. V. Silva, J. de Brito, and R. K. Dhir, "Establishing a relationship between modulus of elasticity and compressive strength of recycled aggregate concrete," Journal of Cleaner Production, vol. 112, pp. 2171-2186, 2016.

[5] U. J. Alengaram, B. A. A. Muhit, and M. Z. b. Jumaat, "Utilization of oil palm kernel shell as lightweight aggregate in concrete-a review," Construction and Building Materials, vol. 38, pp. 161-172, 2013.

[6] K. H. Mo, U. Johnson Alengaram, M. Z. Jumaat, and S. P. Yap, "Feasibility study of high volume slag as cement replacement for sustainable structural lightweight oil palm shell concrete," Journal of Cleaner Production, vol. 91, pp. 297-304, 2015.

[7] E. Yaşar, C. D. Atiş, and A. Kiliç, "High strength lightweight concrete made with ternary mixtures of cement-fly ash-silica fume and scoria as aggregate," Turkish Journal of Engineering and Environmental Sciences, vol. 28, no. 2, pp. 95-100, 2004.

[8] P. Shafigh, M. Z. Jumaat, and H. Mahmud, "Mix design and mechanical properties of oil palm shell lightweight aggregate concrete: a review," International Journal of Physical Sciences, vol. 5, no. 14, pp. 2127-2134, 2010.

[9] P. Shafigh, M. Z. Jumaat, H. B. Mahmud, and U. J. Alengaram, "A new method of producing high strength oil palm shell lightweight concrete," Materials \& Design, vol. 32, no. 10, pp. 4839-4843, 2011.

[10] M. Hassanpour, P. Shafigh, and H. B. Mahmud, "Lightweight aggregate concrete fiber reinforcement-a review," Construction and Building Materials, vol. 37, pp. 452-461, 2012.

[11] A. Sarabèr, R. Overhof, T. Green, and J. Pels, "Artificial lightweight aggregates as utilization for future ashes-a case study," Waste Management, vol. 32, no. 1, pp. 144-152, 2012.

[12] A. M. Neville and J. J. Brooks, Concrete Technology, Pearson Education Asia Pte Ltd., PP (CTP), Malaysia, 2008.
[13] M. M. U. Islam, K. H. Mo, U. J. Alengaram, and M. Z. Jumaat, "Mechanical and fresh properties of sustainable oil palm shell lightweight concrete incorporating palm oil fuel ash," Journal of Cleaner Production, vol. 115, pp. 307-314, 2016.

[14] M. Y. J. Liu, U. J. Alengaram, M. Z. Jumaat, and K. H. Mo, "Evaluation of thermal conductivity, mechanical and transport properties of lightweight aggregate foamed geopolymer concrete," Energy and Buildings, vol. 72, pp. 238-245, 2014.

[15] S. K. A. A. A. Abdus Salam and A. Abdullah, "Lightweight concrete using oil palm shells as aggregates," in Proceedings of National Symposium on Oil Palm by-Products for Agro-Based Industries, Kuala Lumpur, Malaysia, November 1985.

[16] M. A. Mannan and C. Ganapathy, "Long-term strengths of concrete with oil palm shell as coarse aggregate," Cement and Concrete Research, vol. 31, no. 9, pp. 1319-1321, 2001.

[17] D. C. L. Teo, M. A. Mannan, and V. J. Kurian, "Durability of lightweight OPS concrete under different curing conditions," Materials and Structures, vol. 43, no. 1-2, pp. 1-13, 2009.

[18] P. Shafigh, H. B. Mahmud, M. Z. B. Jumaat, R. Ahmmad, and S. Bahri, "Structural lightweight aggregate concrete using two types of waste from the palm oil industry as aggregate," Journal of Cleaner Production, vol. 80, pp. 187-196, 2014.

[19] P. Shafigh, M. Z. Jumaat, and H. Mahmud, "Oil palm shell as a lightweight aggregate for production high strength lightweight concrete," Construction and Building Materials, vol. 25, no. 4, pp. 1848-1853, 2011.

[20] E. Ahmed and H. R. Sobuz, "Flexural and time-dependent performance of palm shell aggregate concrete beam," KSCE Journal of Civil Engineering, vol. 15, no. 5, pp. 859-865, 2011.

[21] U. J. Alengaram, M. Z. Jumaat, H. Mahmud, and M. M. Fayyadh, "Shear behaviour of reinforced palm kernel shell concrete beams," Construction Building Materials, vol. 25, no. 6, pp. 2918-2927, 2011.

[22] M. Maghfouri, P. Shafigh, Z. Binti Ibrahim, and V. Alimohammadi, "Quality control of lightweight aggregate concrete based on initial and final water absorption tests," IOP Conference Series: Materials Science and Engineering, vol. 210, no. 1, article 012022, 2017.

[23] A. A. Abdullah, "Palm oil shell aggregate for lightweight concrete," in Waste Materials Used in Concrete Manufacturing, pp. 624-636, Elsevier, Amsterdam, Netherlands, 1996.

[24] M. A. Mannan and C. Ganapathy, "Engineering properties of concrete with oil palm shell as coarse aggregate," Construction and Building Materials, vol. 16, no. 1, pp. 29-34, 2002.

[25] U. J. Alengaram and U. M. J. K. Awam, Mechanical properties and structural behaviour of palm kernel shell foamed and nonfoamed concrete, Ph.D. thesis, Jabatan Kejuruteraan Awam, Fakulti Kejuruteraan, Universiti Malaya, Kuala Lumpur, Malaysia, 2009.

[26] M. Aslam, P. Shafigh, and M. Z. Jumaat, "Drying shrinkage behaviour of structural lightweight aggregate concrete containing blended oil palm bio-products," Journal of Cleaner Production, vol. 127, pp. 183-194, 2016.

[27] H. Ahmad, M. Hilton, and N. Mohd Noor, "Physical properties of local palm oil clinker and fly ash," in Proceedings of 1st Engineering Conference on Energy and Environment, Kuching, Sarawak, December 2007.

[28] P. K. Mehta and P. J. M. Monteiro, Concrete Microstructure, Properties and Materials, McGraw-Hill, New York, NY, USA, 3rd edition, 2006.

[29] A. A. Abouhussien, A. A. A. Hassan, and M. K. Ismail, "Properties of semi-lightweight self-consolidating concrete 
containing lightweight slag aggregate," Construction and Building Materials, vol. 75, pp. 63-73, 2015.

[30] BS EN 206-1: 2000, Concrete, Specification, Performance, Production and Conformity, 2001.

[31] V. Alimohammadi, M. Sedighi, and E. Jabbari, "Optimization of sulfate removal from wastewater using magnetic multiwalled carbon nanotubes by response surface methodology," Water Science and Technology, vol. 76, no. 10, pp. 2593-2602, 2017.

[32] H. B. Basri, M. A. Mannan, and M. F. M. Zain, "Concrete using waste oil palm shells as aggregate," Cement and Concrete Research, vol. 29, no. 4, pp. 619-622, 1999.

[33] M. A. Mannan, H. B. Basri, M. F. M. Zain, and M. N. Islam, "Effect of curing conditions on the properties of OPS-concrete," Building and Environment, vol. 37, no. 11, pp. 11671171, 2002.

[34] M. Aslam, P. Shafigh, M. Z. Jumaat, and M. Lachemi, "Benefits of using blended waste coarse lightweight aggregates in structural lightweight aggregate concrete," Journal of Cleaner Production, vol. 119, pp. 108-117, 2016.

[35] K. Fujji, S. Adachi, M. T. Takeuchi, M. Kakizaki, H. Edahiro, and Y. Yamamoto, "Properties of high-strength and highfluidity lightweight concrete," ACI Special Publication, vol. 179, pp. 65-84, 1998.

[36] T. A. Holm and T. W. Bremner, State of the Art Report on High Strength, High Durability Structural Low-Density Concrete for Applications in Severe Marine Environments, Engineer Research and Development Center, US Army Corps of Engineers, Washington, DC, USA, 2000.

[37] H. S. Wilson and V. M. Malhotra, "Development of high strength lightweight concrete for structural applications," International Journal of Cement Composites and Lightweight Concrete, vol. 10, no. 2, pp. 79-90, 1988.

[38] P. Shafigh, M. Z. Jumaat, and H. B. Mahmud, "Effect of replacement of normal weight coarse aggregate with oil palm shell on properties of concrete," Arabian Journal for Science and Engineering, vol. 37, no. 4, pp. 955-964, 2012.

[39] ACI Committee 308, "Proposed ACI standard: standard practice for curing concrete," ACI Journal Proceedings, vol. 2, no. 11, pp. $45-55,1980$.

[40] C. D. Atiş, F. Özcan, A. Kılıç, O. Karahan, C. Bilim, and M. H. Severcan, "Influence of dry and wet curing conditions on compressive strength of silica fume concrete," Building and Environment, vol. 40, no. 12, pp. 1678-1683, 2005.

[41] P. Shafigh, U. Johnson Alengaram, H. B. Mahmud, and M. Z. Jumaat, "Engineering properties of oil palm shell lightweight concrete containing fly ash," Materials \& Design, vol. 49, pp. 613-621, 2013.

[42] A. M. Neville, Properties of Concrete, Prentice-Hall, Kuala Lumpur, Malaysia, 14th edition, 2008.

[43] S. Bhanja and B. Sengupta, "Influence of silica fume on the tensile strength of concrete," Cement and Concrete Research, vol. 35, no. 4, pp. 743-747, 2005.

[44] ASTM C 330, "Standard specification for lightweight aggregates for structural concrete," in Annual Book of ASTM Standard, ASTM, West Conshohocken, PA, USA, 2006.

[45] S. H. Kosmatka and M. L. Wilson, Design and Control of Concrete Mixtures, Portland Cement Association, Skokie, IL, USA, 15th edition, 2011.

[46] N. Arioglu, Z. C. Girgin, and E. Arioglu, "Evaluation of ratio between splitting tensile strength and compressive strength for concrete up to $120 \mathrm{MPa}$ and its application in strength criterion," ACI Materials Journal, vol. 103, no. 1, pp. 18-24, 2006.
[47] ACI Committee, Proposed ACI-Standard: Building Code Requirements for Structural Concrete and Commentary (ACI 318M-05), American Concrete Institute, Farmington Hills, MI, USA, 2005.

[48] P. Shafigh, M. Z. Jumaat, H. B. Mahmud, and N. A. A. Hamid, "Lightweight concrete made from crushed oil palm shell: tensile strength and effect of initial curing on compressive strength," Construction and Building Materials, vol. 27, no. 1, pp. 252-258, 2012.

[49] O. Fa, "Prediction of concrete tensile strength from compressive strength: evaluation of existing relations for normal weight concrete," ACI Materials Journal, vol. 88, no. 3, pp. 302-309, 1991.

[50] M. Gesoglu, T. Ozturan, and E. Guneyisi, "Shrinkage cracking of lightweight concrete made with cold-bonded fly ash aggregates," Cement and Concrete Research, vol. 34, no. 7, pp. 1121-1130, 2004.

[51] M. Smadi and E. Migdady, "Properties of high strength tuff lightweight aggregate concrete," Cement and Concrete Composites, vol. 13, no. 2, pp. 129-135, 1991.

[52] F. O. Slate, A. H. Nilson, and S. Martinez, "Mechanical properties of high strength lightweight concrete," ACI Journal Proceedings, vol. 83, no. 4, pp. 606-613, 1986.

[53] D. C. L. Teo, M. A. Mannan, V. J. Kurian, and C. Ganapathy, "Lightweight concrete made from oil palm shell (OPS): structural bond and durability properties," Building and Environment, vol. 42, no. 7, pp. 2614-2621, 2007.

[54] K. G. Babu and D. S. Babu, "Behaviour of lightweight expanded polystyrene concrete containing silica fume," Cement and Concrete Research, vol. 33, no. 5, pp. 755-762, 2003.

[55] L. Gündüz and İ. Uğur, "The effects of different fine and coarse pumice aggregate/cement ratios on the structural concrete properties without using any admixtures," Cement and Concrete Research, vol. 35, no. 9, pp. 1859-1864, 2005.

[56] M. M. Ranjbar, R. Madandoust, S. Y. Mousavi, and S. Yosefi, "Effects of natural zeolite on the fresh and hardened properties of self-compacted concrete," Construction and Building Materials, vol. 47, pp. 806-813, 2013.

[57] S. H. Kosmatka, B. Kerkhoff, and W. C. Panarese, Design and Control of Concrete Mixtures, Portland Cement Association, Skokie, IL, USA, 14th edition, 2002.

[58] C. Satish and L. Berntsson, Lightweight Aggregate Concrete, Science, Technology, and Applications, Noyes Publication/ William Andrew Publishing, New York, NY, USA, 2003.

[59] P. Zia, A. Shuaib, and M. Leming, High-Performance Concretes, a State-of-Art Report (1989-1994), Federal Highway Administration, FHWA-RD-97-030, McLean, VA, USA, 1997.

[60] T. S. Al-Attar, "Effect of coarse aggregate characteristics on drying shrinkage of concrete," Engineering and Technology Journal, vol. 26, no. 2, pp. 146-153, 2008.

[61] M. Aslam, P. Shafigh, and M. Z. Jumaat, "Effect of replacement of oil-palm-boiler clinker with oil palm shell on the properties of concrete," AIP Conference Proceedings, vol. 1774, no. 1 , article 030004, 2016.

[62] A. M. Neville, "Hardened concrete: physical and mechanical aspects," in ACI Monograph No. 6, p. 270, American Concrete Institute, Iowa State University Press, Detroit, MI, USA, 1971.

[63] P. Shafigh, H. B. Mahmud, and M. Z. Jumaat, "Oil palm shell lightweight concrete as a ductile material," Materials \& Design (1980-2015), vol. 36, pp. 650-654, 2012.

[64] R. W. Carlson, "Drying shrinkage of concrete as affected by many factors," American Society for Testing and Materials Proceedings, vol. 38, 1938. 
[65] A. Nilsen and P.-C. Aïtcin, "Properties of high-strength concrete containing light-, normal-, and heavyweight Aggregate," Cement, Concrete and Aggregates, vol. 14, no. 1, pp. 8-12, 1992.

[66] H. Al-Khaiat and M. N. Haque, "Effect of initial curing on early strength and physical properties of a lightweight concrete," Cement and Concrete Research, vol. 28, no. 6, pp. 859-866, 1998.

[67] O. Kayali, M. N. Haque, and B. Zhu, "Drying shrinkage of fibre-reinforced lightweight aggregate concrete containing fly ash," Cement and Concrete Research, vol. 29, no. 11, pp. 1835-1840, 1999.

[68] M. Maslehuddin, M. Ibrahim, M. Shameem, M. R. Ali, and M. H. Al-Mehthel, "Effect of curing methods on shrinkage and corrosion resistance of concrete," Construction and Building Materials, vol. 41, pp. 634-641, 2013.

[69] S. Tongaroonsri and S. Tangtermsirikul, "Effect of mineral admixtures and curing periods on shrinkage and cracking age under restrained condition," Construction and Building Materials, vol. 23, no. 2, pp. 1050-1056, 2009.

[70] M. J. Oliveira, A. B. Ribeiro, and F. G. Branco, "Curing effect in the shrinkage of a lower strength self-compacting concrete," Construction and Building Materials, vol. 93, pp. 1026-1215, 2015.

[71] M. B. West, "Effect of materials and curing period on shrinkage of concrete," Doctoral Dissertation, Project No. TPF-5(051)-SM Report No. 98, p. 269, University of Kansas Center for Research, Lawrence, KS, USA, 2010.

[72] A. M. Neville, Properties of Concrete, John Wiley \& Sons Inc., New York, NY, USA, 1996.

[73] J. A. Bogas, R. Nogueira, and N. G. Almeida, "Influence of mineral additions and different compositional parameters on the shrinkage of structural expanded clay lightweight concrete," Materials \& Design (1980-2015), vol. 56, pp. 1039-1048, 2014. 


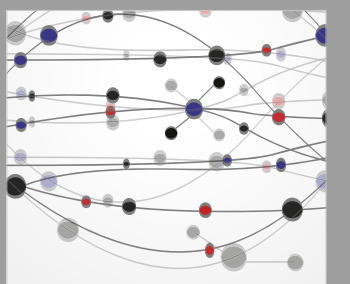

The Scientific World Journal
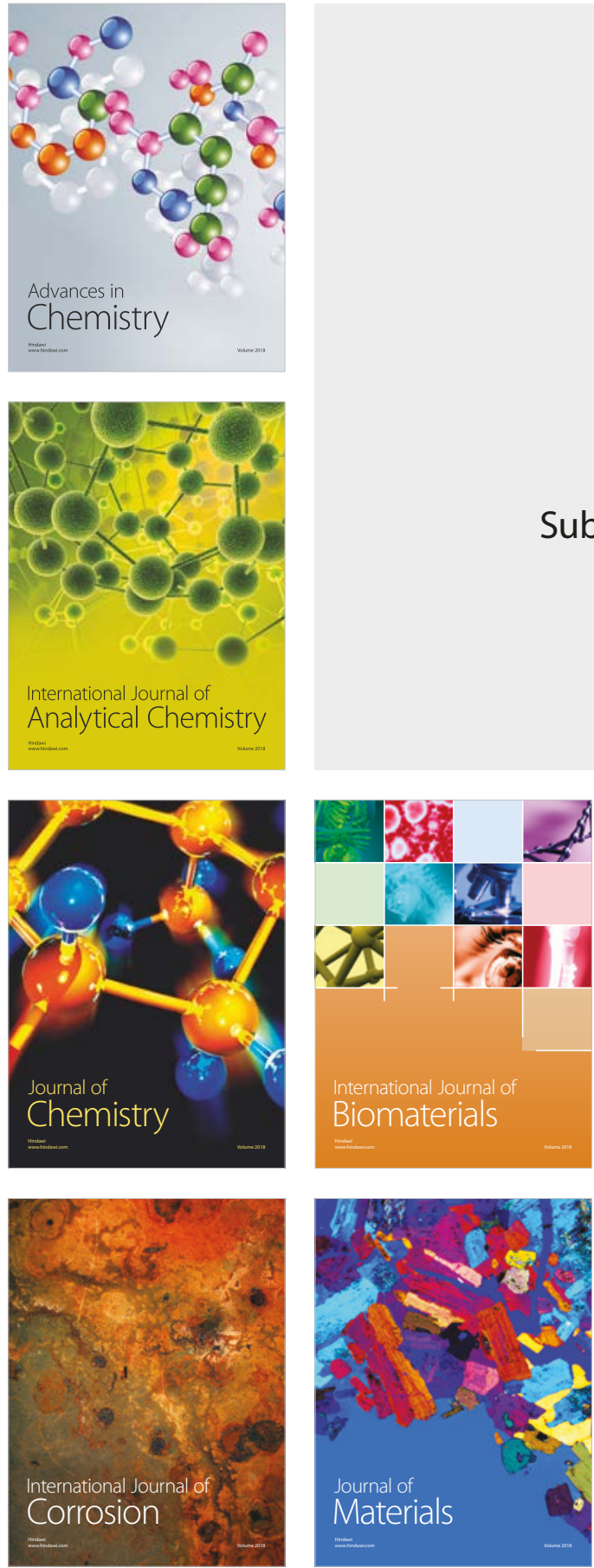

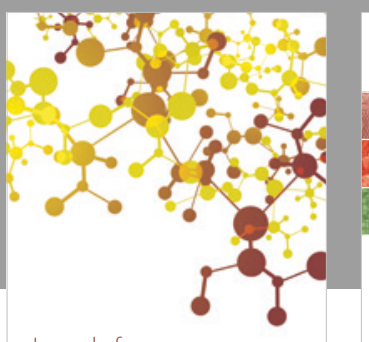

Journal of

Applied Chemistry
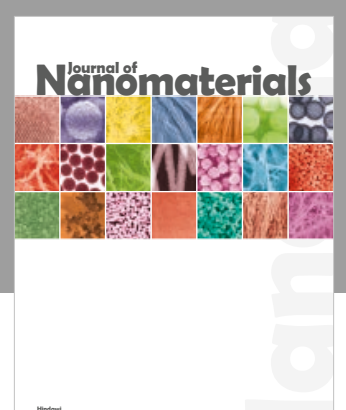

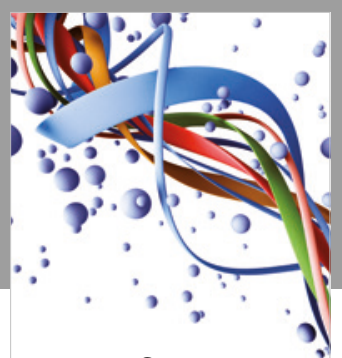

Scientifica

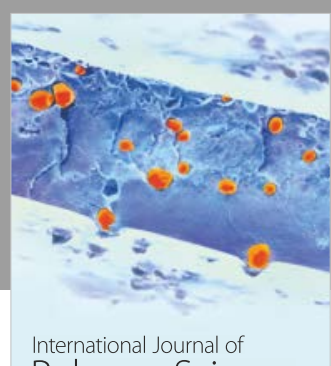

Polymer Science

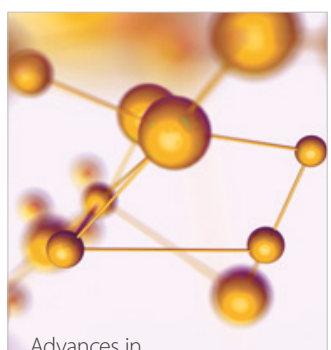

Physical Chemistry
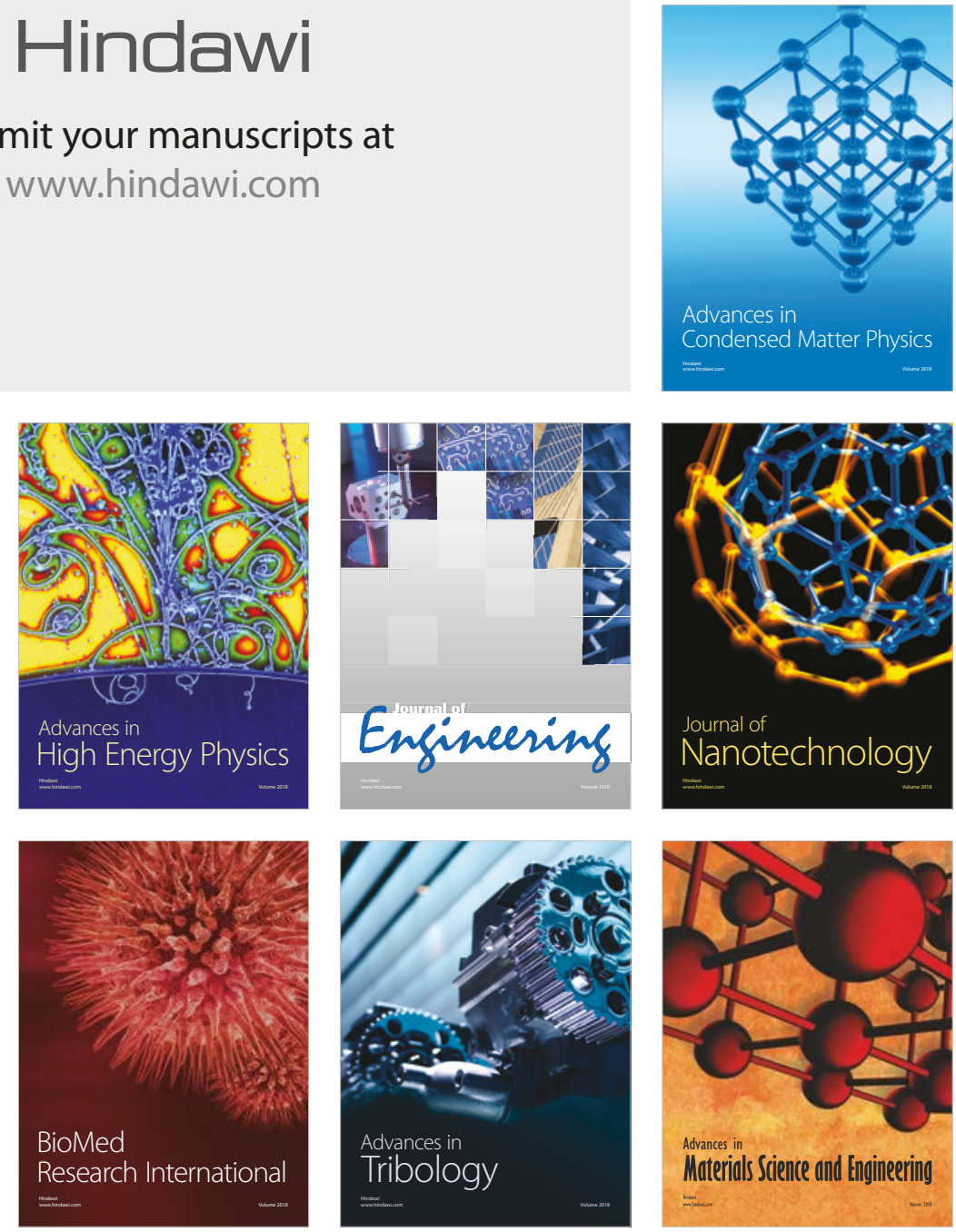